\section{PERSPEKTIF HISTORIS CAMPURSARI DAN CAMPURSARI ALA MANTHOU'S}

\section{Joko Tri Laksono}

\section{Etnomusikologi Fakultas Seni Pertunjukan ISI Yogyakarta}

\section{Abstract}

Campursari is an ensemble of a highly and aesthetically musical taste of various musical instruments, each of wich has distinctive characteristics and playing patterns. The problems arising from the difference in the system of notation and harmony can be overcome in so far each, musician is aware of the importance of togetherness needed in the musical performance. In history instrumentation of campursari cannot leave karawitan and music keroncong which represents beginning at first merger from bath the ensembles. Manthou's as originators campursari tries to alli the instrumentation becames one fully unity especially about its tune.

Kata kunci: musik campursari, perspektif historis

\section{PENDAHULUAN}

Seni kehadirannya di dunia ini senantiasa dibutuhkan oleh setiap manusia di manapun mereka berada dan kapan saja. Dengan demikian secara sederhana dapat dikatakan bahwa perkembangan seni selalu seiring dengan masyarakat pendukungnya. Pada masyarakat primitif seni hampir segala-galanya, mengingat setiap kegiatan manusia yang mengalami krisis dalam hidupnya karena menginjak tahap hidup tertentu senantiasa memerlukan seni. Hal ini sangat memungkinkan karena sistem kemasyarakatan mereka bersifat komunal, maka seni mereka pun berciri komunal yang dilakukan bersama-sama, akibatnya gaya penampilan seni kelompok etnis primitif boleh dikatakan seragam.

Ketika sebuah masyarakat mengalami perubahan tata kehidupan politiknya menjadi negara yang merdeka dan demokratis, akan lahir pula seni yang sangat menonjolkan kebebasan serta mementingkan individu. Pada era inilah kita selalu mengatakan lagu yang demikian komponisnya itu; dan tari yang begitu adalah karya koreografer itu. Kemudian ketika terjadi perubahan tata politik yang kita sebut orde baru yang mencuat setelah tahun 1965, ketika kebebasan individu mulai "dijamin" mulailah bermunculan karya-karya individual di mana-mana. Namun jelas bahwa penciptaan sebuah karya seni selalu memiliki tujuan. Secara garis besar, tujuan itu bisa dikelompokkan menjadi tiga, yaitu: (1) seni untuk tujuan ritual; (2) seni sebagai hiburan pribadi; dan (3) seni untuk tujuan presentasi estetis.

Kebebasan individual yang telah dijamin dan mengalami perkembangan hingga sekarang ini telah memunculkan berbagai macam eksplorasi karya-karya seni seperti: adanya perpaduan antara budaya timur dan barat. Akibat dari itu terjadilah perpaduan budaya dalam tulisan ini adalah seni musik khususnya campursari.

Campursari (khususnya ala Manthou's) yang muncul pada dekade 90an, sempat melejit bahkan ada kecemasan bagi para niyaga apabila berkelanjutan campursari dapat memporak-porandakan kesenian tradisional khususnya seni karawitan. Campursari secara ensambel merupakan perpaduan antara alat musik/instrumentasi, tangga nada pentatonis dan tangga nada diatonis, dan penyajiannya. Repertoar lagu-lagu yang disajikan cukup bervariasi dapat berjenis klenengan, keroncong, pop, dan dangdut.

Lagu campursari karya Manthou's apabila ditelaah lebih lanjut mempunyai ciri-ciri tersendiri baik berdasarkan melodi dari lagu yang diciptakan, syair lagunya, maupun latar belakang lagu diciptakan. Masyarakat (terutama pandhemen campursari) secara cepat akan mengenal lagu ciptaan Manthou's bahkan hafal lirik lagu dan syairnya, walaupun album baru saja diluncurkan. Tidak dapat dipungkiri campursari Manthou's selalu menjadi kiblat bagi grup campursari lainnya.

Penelusuran tentang melodi lagu dan syairnya dapat menggunakan pendekatan secara tekstual. Tekstual di sini diartikan bagaimana memandang sebuah fenomena kesenian (musik, tari, sastra, sastra lisan, dan sebagainya) sebagai suatu teks yang relatif berdiri sendiri. Untuk penelaahan secara mendetail bagaimana lagu tersebut diterima dalam kehidupan masyarakat dapat dikaji dengan pendekatan kontekstual. Kontekstual di sini oleh Shri Ahimsa dijabarkan merupakan sebuah kajian yang menempatkan fenomena tersebut dalam konteks yang lebih luas, yakni konteks sosial budaya masyarakat tempat fenomena seni tersebut muncul atau hidup. Tetapi prinsip yang mendasar adalah menelaah tentang terjadinya akulturasi dalam ensambel campursari dalam beberapa sisi.

\section{MENGENAL CAMPURSARI}

\section{Pengertian Campursari}

Istilah Campursari secara etimologis dibentuk dari dua suku kata bahasa Jawa, yakni campur dan sari. Istilah campur mempunyai banyak pengertian, antara lain: campur, kasar, dalam keadaan kotor, cemar, campuh. Begitu pula halnya istilah sari juga mempunyai bermacam-macam arti misalnya: inti sari, yang terbaik dari sesuatu, bagian yang paling berharga, tepung sari. Dari sekian banyak pengertian yang terkandung dalam dua istilah tersebut (campur dan sari) keterkaitannya dengan penulisan ini yang selaras adalah campur atau pencampuran, sedangkan sari adalah intisari atau bagian yang paling berharga.

Berangkat dari pemilihan pengertian tersebut di atas akhirnya ditemukan gabungan pengertian bahwa campursari adalah penggabungan antara bagian yang 
paling berharga atau pokok/penting dari sebuah benda atau sesuatu. Melihat proses yang demikian ensambel ini dikatakan perwujudan dari sebuah akulturasi. Masalah akulturasi itu sendiri selaras dengan pendapat Kodiran yakni,

"Akulturasi akan terjadi apabila terdapat dua kebudayaan atau lebih yang berbeda sama sekali (asing dan asli) berpadu sehingga prosesproses ataupun penebaran unsur-unsur kebudayaan asing secara lamba laun diolah sedemikian rupa ke dalam kebudayaan asli dengan tidak menghilangkan identitas maupun keasliannya”.

Ensambel campursari adalah pencampuran atau perpaduan flute-yang kemudian berkembang pada instrumen keyboard, cukulele, cak, bass-yang kemudian berkembang dengan bass gitar elektrik, dengan instrumen pokok dalam ensambel karawitan atau tepatnya ensambel cokekan (yang dipergunakan dalam campursari awalnya hanya instrumen kendang, siter, dan gong, namun kemudian berkembang dengan saron barung dan demung).

Pengertian campursari oleh penggagasnya (Manthou's) adalah perpaduan instrumen gamelan dan instrumen Barat yang tentu juga terkait dengan penggabungan tangga nada pentatonis dan tangga nada diatonis. Penggunaan istilah campursari dalam ensambel musik adalah mirip dengan campursari pada lazimnya yang digunakan orang untuk menyebut sesuatu yang dicampur dari dua atau lebih unsur yang berbeda.

Ciri ensambel campursari yang dimaksud dalam pemaparan ini, tidak hanya ditandai dengan percampuran instrumen gamelan Jawa dengan instrumen musik Barat saja, akan tetapi percampuran kedua tersebut yang masing-masing diwakili oleh ciri-ciri tertentu. Hal ini dapat dilihat dari bentuk fisik maupun tangga nada dari kedua instrumen yang tergabung dalam kesatuan ensambel campursari. Namun perlu diingat bahwa sebuah penggabungan tersebut tidak berarti tanpa akibat, baik dilihat dari sudut kebudayaan maupun aspek sosial.

Semua masyarakat dan kebudayaan yang hidup di dunia ini selalu bergerak, berubah dan berkembang. Hal ini selaras dengan kenyataan bahwa campursari tidak dapat terlepas dengan pembahasan pertemuan kebudayaan antara musik keroncong dengan kebudayaan musik Jawa, yang kemudian berubah menjadi ensambel baru dalam dunia musik.

\section{Sejarah Campursari}

Campursari yang ngetrend pada tahun 90-an, muncul tepatnya pada tahun 1994 yang sempat melibas kesenian tradisi khususnya karawitan karena kemampuannya menyajikan lagu baik bertangga nada pentatonis (wilayah karawitan) dan diatonis (wilayah musik barat). Campursari adalah sebuah ensambel musik hasil usaha musisi Jawa untuk menyesuaikan dengan perkembangan zaman.
Hal ini selaras dengan pendapat Manthou's selaku pencetus ensambel tersebut yang pada akhirnya menjadi kiblat bagi grup-grup campursari yang baru. Lebih lanjut Manthou's mengatakan bahwa ensambel ini dibuat untuk memenuhi tuntutan selera masyarakat dari berbagai kalangan terutama kawula muda, namun tidak meninggalkan unsur tradisi yang telah ada. Ensambel tersebut terdiri dari instrumen gamelan Jawa, instrumen keroncong serta instrumen electric yang dapat digunakan untuk memainkan repertoar-repertoar lagu atau gendhing-gendhing Jawa, keroncong, dangdut serta lagu lainnya. Dengan demikian untuk kalangan tua dapat disajikan jenis lagu langgam ataupun gendhing-gendhing, keroncong yang telah diaransemen, demikian pula untuk kalangan muda dapat disajikan jenis lagu pop maupun dangdut.

Embrio campursari sudah ada sejak tahun 1960-an dimulai dari studio RRI Surakarta yang berusaha memadukan ensambel keroncong dengan instrumen siter dan kendhang batangan, terus berkembang di RRI Semarang. Pada saat itu campursari belum mendapat tanggapan dari masyarakat dan ditinggalkan karena dinilai keluar atau nyebal dari pakem. Terlebih pada tahun 1970-an Waljinah mampu mendobrak dengan mempopulerkan langgam Jawa berjudul "Kembang Kacang dan Walangkekek" yang pada akhirnya menghantarkan namanya dengan sebutan "Waljinah Walangkekek".

Pada tahun 1994 Manthou's membuat grup campursari dan langsung membuat rekaman dengan repertoar langgam Jawa dan gendhing Jawa. Untuk teknik perekaman dan studio yang mau merilis lagu-lagu ciptaan Manthou's bukan hal yang asing bagi dia, karena puluhan tahun bekerja di Musica Record Jakarta. Selain itu, Manthou's merupakan pencipta lagu yang handal terbukti lagu ciptaannya "Surga dan Neraka" yang dibawakan Hetty Koes Endang tahun 1970, "Jamilah" yang dilantunkan Jamal Mirdad 1984 dan "Gethuk" yang melejit lewat suara emas Nur Afni Octavia tahun 1989, bahkan "Kangen" melalui suara emas Evi Tamala sempat menggebrak dunia musiki tahun 80-an. Untuk strategi penjualan khususnya lagu campursari ini, Manthou's menciptakan lagu berjudul "Kanca Tani" yang dilantunkan Waljinah "Walangkekek". Hal tersebut bukan tanpa alasan, karena dengan memilih penyanyi Waljinah, Manthou's berharap lagu dan jenis genre musik campursari tersebut dapat diterima oleh masyarakat khususnya para petani yang saat itu masih banyak yang gandrung dengan penyanyi Waljinah.

\section{Keroncong dan Gamelan Awal Mula Campursari}

Pembahasan campursari tidak dapat lepas dari pembahasan pertemuan kebudayaan musik keroncong dengan kebudayaan musik Jawa yakni gamelan. Pertemuan ini sebenarnya telah lama terjadi yakni pada tahun 1940-an sebagai akibat larangan penjajah Jepang kepada bangsa Indonesia membunyikan musik 
Barat. Untuk itu musisi Jawa membuat sebuah ensambel yang instrumennya menggunakan instrumen musik keroncong, akan tetapi lagu dan aransemennya memasukkan unsur gamelan Jawa. Pertemuan ini menghasilkan satu jenis lagu keroncong yang disebut langgam Jawa.

Musik keroncong di dalamnya ada empat jenis lagu, yakni keroncong asli, stambul, langgam keroncong, dan langgam Jawa. Perbedaan antara lagu yang satu dengan lagu lainnya terletak pada bentuk lagu, jumlah bar, dan atau tangga nada. Lagu keroncong asli terdiri dari tiga bagian yang masing-masing bagian berbeda (A, B, dan C), stambul hanya dua bagian (A dan B), langgam keroncong dan langgam Jawa juga merupakan lagu tiga bagian akan tetapi lagu pertama dan kedua mirip (A1, A2, dan B). Keroncong asli dan stambul tidak menggunakan refrain sedangkan langgam keroncong dan langgam Jawa menggunakan refrain Keroncong, stambul, dan langgam keroncong bertangga nada diatonis, langgam Jawa bertangga nada pentatonic.

Secara etimologis langgam artinya gaya, model, cara. Langgam keroncong adalah jenis lagu keroncong yang digarap secara keroncong, sedangkan langgam Jawa adalah jenis lagu keroncong yang digarap secara Jawa (gamelan Jawa) yang aransemennya dipengaruhi oleh aransemen gamelan Jawa.

\section{Langgam Keroncong dan Langgam Jawa}

Perbedaan yang menyolok aransemen langgam keroncong dengan langgam Jawa terletak pada tabuhan instrumen cuk, cak, cello, dan bass. Tabuhan (pola permainan) cuk, cak, cello, dan bass pada keroncong asli, stambul, dan langgam keroncong sama tidak ada perbedaan yang mendasar. Tetapi pola permainan dalam langgam Jawa menirukan teknik tabuhan instrumen yang ada dalam gamelan Jawa. Instrumen cuk menirukan tabuhan engkuk kemong dan imbal bonang, cak menirukan tabuhan siter, cello menirukan tabuhan kendhang batangan dan bass menirukan tabuhan balungan atau melodi pokok pada karawitan Jawa (terutama instrumen slenthem).

Perbedaan lain yang dapat dikemukakan adalah langgam Jawa dalam penyajiannya juga menggunakan irama yang biasa disajikan dalam karawitan Jawa, misalnya irama rangkep walaupun penerapannya kurang jelas. Irama rangkep dalam langgam Jawa hanya digunakan untuk irama dengan tempo dua kali lebih lambat dari tempo moderato. Perubahan tempo ini mengakibatkan perubahan tabuhan cuk yang dilipatkan dua kali dari pukulan biasa. Pada tabuhan cuk, tempo lambat atau irama rangkep menggunakan pola tabuhan imbal pada instrumen bonang barung dan bonang penerus atau instrumen saron barung 1 dan saron barung 2 .

Manifestasi dari pernyataan di atas, apabila dibandingkan pola permainan (tabuhan) instrumen cuk, cak, cello, dan bass dapat dilihat sebagai berikut.

\section{Langgam Keroncong}

uk

ak

ello

1

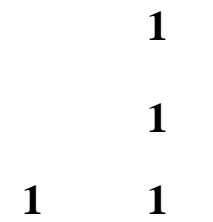

1

ass

\section{Langgam Jawa}

uk

ak

356356356356356323356323356

b

ello

$$
\text { p p . lp p p }
$$

d

$\operatorname{lp} \mathbf{L p} \mathbf{t}$

Perbedaan lainnya adalah langgam keroncong dalam penyajiannya tanpa menggunakan bawa, sedangkan langgam Jawa kebanyakan menggunakan bawa gawan gendhing. Selain itu, langgam keroncong disajikan dalam tangga nada diatonis, sedangkan langgam Jawa disajikan dengan tangga nada pentatonis.

Langgam Jawa dan gendhing langgam merupakan pertemuan kebudayaan musik Jawa dengan kebudayaan musik keroncong tidak berhenti pada lagu langgam Jawa saja, akan tetapi juga dapat dijumpai pada gendhing langgam. Apabila dalam langgam Jawa teknik tabuhan keroncong menirukan teknik tabuhan instrumen gamelan Jawa, pada gendhing langgam sebaliknya teknik tabuhan instrumen gamelan menirukan teknik tabuhan langgam keroncong.

\section{SIMPULAN}

Campursari mempunyai mata rantai sejarah yang panjang dan berkembang sesuai dengan konsep perubahan kebudayaan. Meskipun campursari merupakan bentuk ensambel baru, namun apabila dilihat dari alur sejarahnya mempunyai mata rantai dengan kesenian yang sebelumnya (keroncong dan langgam Jawa). Perubahannya tentu berjalan perlahan-lahan sesuai dengan kehendak masyarakatnya dan dalam perubahan juga menyerap unsur-unsur musik 
yang ada di sekitarnya.

Percampuran unsur-unsur musik dalam ensambel campursari didominasi oleh unsur musik keroncong dan gamelan Jawa, namun tidak mengesampingkan instrumen musik Barat. Keterpaduan dari beberapa ensambel, yakni keroncong, gamelan Jawa, dan musik Barat dengan mengalami proses yang akhirnya membentuk jati diri ensambel campursari, membuktikan bahwa adanya akulturasi pada ensambel campursari tersebut.

Gamelan Jawa yang merupakan kesenian tradisi/asli masyaraka setempat (Jawa pada khususnya) mendapat pengaruh dari musik Barat/asing dan secara tangga nada yang berbeda dari ensambel keroncong/asing, membuktikan terjadinya akulturasi sangat jelas. Walaupun harus diakui bahwa perubahan tersebut (akibat dari akulturasi) tentu mengandung dampak dari kedua kebudayaan masing-masing.

Akulturasi dalam ensambel campursari dapat ditelaah dalam sisi setting instrumen dan bentuk penyajian, instrumentasi, dan tangga nada. Secara fisik instrumen tradisi masih nampak karena memang tidak ada perubahan. Namun apabila dicermati terjadi perubahan dalam tangga nada, yang kesemuanya untuk mendapatkan keterpaduan yang pulet terutama terkait rasa musikal itu sendiri. Satu hal yang tidak dapat dipungkiri bahwa nada adalah merupakan unsur yang paling mendasar dalam musik.

Sampai kapan campursari akan hidup dan berkembang, tentu semua tergantung kepada masyarakat pendukungnya. Hal itu dikarenakan mati hidupnya sebuah kebudayaan terlebih khusus pada kesenian sangat tergantung pada fungsi kesenian itu sendiri terhadap masyarakat pendukungnya.

\section{DAFTAR PUSTAKA}

Birawa, Kochil. 1998. "Manthou's: Pencetus Campursari”. Kedaulatan Rakyat Edisi Minggu Pon. 21 Juli 1998.

Harmunah. 1996. Musik Keroncong. Yogyakarta: Pusat Musik Liturgi.

Kodiran. 1998. "Akulturasi sebagai Mekanisme Perubahan Kebudayaan" dalam Humaniora No 8 Periode Juni - Agustus 1998 Fakultas Sastra Universitas Gadjahmada, 1998.

M. Moeljono, Anton. 1990. Kamus Besar Bahasa Indonesia. Jakarta: Balai Pustaka,

Manthou's. 1997. "Selayang Pandang tentang Campursari Gunungkidul Maju Lancar" Makalah yang disajikan dalam seminar campursari di Taman Budaya Yogyakarta, 22 Februari 1997.

Radcliffe Brown, A.R. 1980. Struktur dan Fungsi dalam Masyarakat Primitif. Terj. Abdul Razak Yahya. Kuala Lumpur: Percetakan Dewan Bahasa dan Pustaka.
Shri Ahimsa Putra, Heddy. 1998. "Sebagai Teks dalam Konteks: Seni dalam Kajian Antropologi Budaya" dalam Seni: Jurnal Pengetahuan dan Penciptaan Seni Edisi VI/01 - Mei 1998. Yogyakarta: BP ISI Yogyakarta.

Shri Ahimsa Putra, Heddy. 2000. Penyunting. "Wacana Seni dalam Antropologi Budaya" dalam Ketika Orang Jawa Nyeni. Yogyakarta: Galang Press.

Soedarsono, R. M. 1999. Seni Pertunjukan dan Pariwisata (Rangkuman Esai tentang Seni Pertunjukan dan Pariwisata). Yogyakarta: BP ISI Yogyakarta.

Soedarsono, R. M. 1999. Metode Penelitian Seni Pertunjukan dan Seni Rupa. Bandung: MSPI.

Zoetmulder. 1995. Kamus Jawa Kuna - Indonesia. Jakarta: PT. Gramedia Pustaka Utama. 